\title{
Issues in Regional Linguistics and Tools of Modern Linguistic Research: \\ Introduction to the Linguistic Edition of the Journal of Siberian Federal University
}

\author{
Ekaterina S. Muchkina and Oksana V. Magirovskaya* \\ Siberian Federal University \\ Krasnoyarsk, Russian Federation
}

Received 24.09.2020, received in revised form 18.10.2020, accepted 14.12.2020

\begin{abstract}
The $21^{\text {st }}$ century linguistic research is becoming different. It is due to both new challenges and strivings for wider coverage of the language map of the world. The latter manifests itself in an unprecedented interest in indigenous languages that are in urgent need of analysis as they show the paths to deeper penetration into regional cultures and greater awareness of their representatives' mentality. No less important are new linguistic descriptions of Oriental and European discourse practices that currently develop and reveal the nations' mentality as well as their patterns of verbal and nonverbal behaviour. Present-day linguistics also focuses on the issues that have previously been beyond its scope. It has become collaboratively expansive with other fields of knowledge, providing significant scientific ground for the analysis of sign languages and speech disorders. Rich methodological basis, a variety of approaches and tools, well developed theories and conceptions form a profound theoretical and empirical foundation for modern linguistic research and largely facilitate its further development.
\end{abstract}

Keywords: regional linguistics, linguo-cultural heritage, digital tools of analysis.

Research area: philology.

Citation: Muchkina, E.S., Magirovskaya, O.V. (2020). Issues in regional linguistics and tools of modern linguistic research: introduction to the linguistic edition of the Journal of Siberian Federal University. J. Sib. Fed. Univ. Humanit. Soc. Sci., 13(12), 1896-1901. DOI: 10.17516/1997-1370-0707.

\footnotetext{
(C) Siberian Federal University. All rights reserved

* Corresponding author E-mail address:mes_kras@mail.ru, magirovskayaov@yandex.ru ORCID: 0000-0002-7173-0583 (Muchkina); 0000-0003-4286-2613 (Magirovskaya) 
This issue of the Journal of Siberian Federal University. Humanities \& Social Sciences follows a tradition of linguistic issues dealing with topics of current interest in the field of regional linguistics. Such trend in linguistic research theoretically and empirically confirms that "language variation and change highlight the fact that language universally involves alternative forms and structures that compete with each other in usage" (Krug, Schlüter, Rosenbach, 2013: 1). Taken into account and thoroughly analyzed, regional aspects serve an invaluable source of information about the nature of language and the ways it develops.

The articles that cover this area of current research in the issue offer their view on a number of indigenous languages, primarily the languages of Siberia, in their various perspectives. They identify and describe the main trends and principles currently developed by linguists - revitalisation and preservation of intangible cultural heritage through the study of regional concepts, indigenous literature, regional sign languages as well as changing attitudes to indigenous languages. All this suggests that "we have appeared to have developed a striking international shared agenda" (Brumfit, 2004: 135).

Of equal importance are the papers that present the results gained when the latest digital tools of analysis are applied to national literary heritage. Such tools have an incalculable practical value as they can be applied to the study of big fiction corpora, identification of authorships, diagnosing speech disorders, etc.

The first article "Siberia/Sibir/Sibir'/Sybir: What's in a Name?" by Elena V. Beloglazova and Viktor V. Kabakchi (St. Petersburg) focuses on the issue of language contacts and their orientation towards external cultures. The authors treat Siberia as a unique linguistic sign and cover the set of English-language equivalents to the Russian "Сибирь", i.e. Siberia and Sibir, with the emphasis on distinctions between them in both meaning and stylistic functions, passing then onto the problem of conceptualizing 'Siberia' through the English-language means. The study reveals that in the English-speaking world Sibir tends to serve as a marker of the Soviet discourse and as a coinage open for new contextual meanings, which can be "the original, genuine land, the home of aboriginal cultures and nature" or "the name of a certain entity (newspaper, company)". Siberia, in its turn, is more widely exploited in fiction and is associated with exile, cold, unfriendliness, and vastness. This opposition confirms a complex and constantly developing nature of toponymic concepts with their potential to embrace stereotypical and often mythological cultural knowledge.

The article "The Concept of Stolby Nature Reserve in the Aspect of Linguoimagelogy" by Irina V. Evseeva and Irina S. Zhmakina (Krasnoyarsk) presents the image modeling of the National Park in Krasnoyarsk (Siberia) based on the exclusive properties of this geographical and cultural object. Through the linguo-cognitive analysis of numerous publicistic texts about the National Park, the components of the concept under study were identified; a frame-type model was built, providing for the conceptual, pragmatic and evaluative characteristics of the frame slots; the types of estimated values prevailing in the texts about the National Park were determined; the frequency of linguistic means - artistic tropes used in creating a positive image of the object under study - has been established as well. All this provides relevant methodological basis for the further analysis of toponymic objects with regional and/or national significance.

In this issue we delve into specific problems that highlight the need for further research into semiotic systems different from the verbal one. The article "Specific Features and Patterns of Conceptualizing the Emotions and Feelings in Sign Language (the Case of the Regional Variant of the Russian Sign Language in the Republic of Khakassia)" by Oksana V. Magirovskaya, Ekaterina S. Privalikhina and Violetta S. Srmikian (Krasnoyarsk) claims that, like spoken languages, national sign languages embrace numerous regional variants. Yet, their scope is greater and the gap between them is deeper, since they cover the communicative needs of closed social groups of deaf people and people with hearing impairments. The research reveals key patterns of knowledge formation peculiar for the 
Khakass variant of the Russian sign language and illustrates this with the signs representing emotions and feelings. It discovers that sign conceptualization of emotions and feelings is most often based on signers' inner experience and, thus, confirms the conceptualizing potential of sign language as an autonomous semiotic coding system.

A linguistic debate might be sparked by the article "Changing Attitudes Toward Indigenous Languages in Russia: Some Evidence from the North" by Erzhen V. Khilkhanova (UlanUde) who examined the changing dynamics of attitudes toward indigenous languages in the USSR and the Russian Federation. The scholar points at a positive change of language attitudes in the Republic of Buryatia, one of the Siberian regions, over the last decade and provides relevant evidence for it by carrying out a psychosociolinguistic experiment.

The article "Russian Open Education Centre "Siberia.ru": the Conceptual Bases and Prospects for Development" by Galina A. Kopnina, Irina V. Evseeva, Ekaterina V. Eremina, Tatiana K. Verenich and Irina V. Bashkova (Krasnoyarsk) carried out as part of a grant project supported by the Ministry of Education of the Russian Federation, reflects on the priority area of Siberian Federal University mission related to the popularization of the Russian language, literature and Russian culture abroad. Though the Centre was officially opened online in October 2020, more than1400 learners from 78 countries have already signed up for the distance courses and workshops offered on the Center's website, which is the best justification for its timely launch. The brief overview of similar centres for open education in Russia shows that their aims and objectives as well as the mission vary a lot. In this connection, the main goal of the Centre at SibFU is considered to be an extensive and sufficient list of e-courses on the e-Siberia platform - the online learning tool of the Siberian Regional Centre of Competence in Krasnoyarsk. The article also sets the priorities for further work of the Centre such as the development of distant online courses for non-Russian learners to support schooling and Russian culture through the contents; the arrangement of methodological online seminars to exchange the experience gained; the promotion of the Centre and its educational activities and cultural events on social networks in different languages.

In the subsequent paper "Comparative Research of Attitudes to Mediation at Galician and Siberian Universities" by Julia V. Popova, Artem A. Smolyaninov (Krasnoyarsk) and Maria del Mar Lorenzo Moledo (Santiago de Compostela), mediation in a university environment is the issue in the focus of the authors' attention. The comparative analysis of mediation techniques used by the staff of both universities (SibFU and Galician University) proved that the introduction of mediation techniques, services and initiatives contributes much to the creation of a conflictfree environment at a university level.

In the article "Speech Disorders Testing: Practices of European and Russian Clinical Linguistics" Natalia G. Burmakina, Iulia I. Detinko, Liudmila V. Kulikova and Iana V. Popova (Krasnoyarsk) discuss different testing methods for diagnosing speech disorders caused by local brain damage. The authors present seven tests developed in European countries and Russia from the 40s of the 20th century till present. Four out of these methods have passed significant approbation and are widely used for testing the speech of the patients with aphasia; the other three methods were introduced recently and reflect the current data from neurolinguistics, neuropragmatics, research of metalinguistic abilities and augmentative/alternative communication. It is noted that there is a culturally specific marker of diagnosis in accordance with the research traditions of different countries as well as cognitive and mental characteristics of the patients who speak different languages. The authors emphasize that the prospects for diagnosing speech localization in the brain are found in the combination of methods of neuropsychology and neuroimaging and in the use of artificial intelligence which implies the joint efforts of speech therapists, linguists, neurologists, and neuropsychologists.

The next article "Discursive Strategies of Legitimating Institutionalized Values in 
Educational Settings: Experience of Japan" by Anastasia V. Kolmogorova and Anna V. Kozachina (Krasnoyarsk) discusses the role of discursive tools in shaping the value picture of the world in Japanese schoolchildren. The linguistic research is based on the texts taken from the textbook "Moral Education". The authors focus on discursive strategies and linguistic means of legitimation, advancing into the collective consciousness of the Japanese as well as modern values, the implementation of which is necessary in the global conditions of a changing world, and traditional values, dating back to distant history and "faded" over time.

The following few papers focus on the issue of common ground: how different images and semantic categories are verbalised in indigenous literature. Svetlana S. Imikhelova and Eugeny D. Mongush (Ulan-Ude) in their article "Archetypical Image of the Old Man in Buryat Literature of the 20th Century" investigate typological properties of the Old Man's archetypical image in modern Buryat literature. The comparative-typological method helps the authors to distinguish such typological features and properties of the Old Man's archetype as ambivalence, poetry and ontology of binary oppositions as well as crave for a miraculous outcome. These properties give the analyzed character the symbolic meaning of eternal rebirth, the cyclicity of life and its harmonious order.

Saodat E. Kamilova and Yana Yu. Arustamyan's article "Original Projection of Author's "Self" in Modern Russian and Uzbek Short Story" (Uzbekistan) moves on from issues of short story genre peculiarities in Russian and Uzbek literature of the late $20^{\text {th }}$ and early $21^{\text {st }}$ centuries into the triad "authornarrator-character". These three components are connected at one point as the author becomes both the narrator and the protagonist of a short story or even coincides with the narrator. This leads the authors to a classification of the types of the author's "Self", which is represented by introverted, juvenile retrospective and lyrical types of the author's "Self" in both Russian and Uzbek short stories. Their specific features, if taken into consideration, favour the analysis of various associative links between different author's categories.

Another set of articles draws on corpuses as a source of invaluable illustrative material for linguistic research. Mikhail Yu. Mukhin and Nikolai Yu. Mukhin's paper (Ekaterinburg) "Idiostyle Characteristics of Lexical Compatibility in the $19^{\text {th }}$-century Prose: Ural Stylometric Project" gives insight into idiostylistic characteristics of five Russian $19^{\text {th }}$-century writers. To reach their objectives, the authors do a comparative statistical analysis of lexical bigrams, i.e. two lexemes of significant parts of speech located in one phrase context at a distance of no more than five words, typical for the works of each writer. The proposed model of syntagmatic analysis might further lead to the development and systematization of philological judgments about the writers' lexical compatibilities.

Alexey I. Gorozhanov and Innara A. Guseynova (Moscow) in the article "Corpus Analysis of the Grammatical Categories' Constituents in Fiction Texts Considering the Lingo-Regional Component" describe the application of three computer programs to the linguistic analysis of Franz Kafka's novel "Das Schloss". The programs allow investigating the constituents of the grammatical categories of certainty/uncertainty and modality as well as individual grammatical phenomena. The article has a high linguodidactic value as the described model of corpus-based material analysis might be widely used in class and in translation.

The following article "Volume 91": An Electronic Index to the Complete Works of Leo Tolstoy" by Boris V. Orekhov (Moscow) might serve as a source of inspiration for those who attempt to design effective tools for literature analysis and interpretation of big fiction corpora. Providing an example of how a digital index can serve as a starting point for local history research and introducing useful tools for the analysis of both the text structure and its constructive components, the author declare further perspectives the digital applications open up for a wide range of philological studies. 
The article "Anonymous vs. Attributed: Cluster Analysis of Tolstovskii Sbornik Texts and Its Interpretation in Terms of Cultural Heritage" by Oleg F. Zholobov (Kazan), Victor A. Baranov (Izhevsk) and Maria O. Novak (Moscow) tracks the contributions of the cluster analysis to modern linguistic research. This analysis makes it possible to identify several thematic keys in Cyril of Turov's homilies as well as to establish a distinguishing feature of his preaching discourse - a widespread use of role deixis. The analysis also comes in useful when identifying the authorship of several homilies.

As always, preparation of this journal issue is more or less a joint effort, and there are a great number of people who have contributed to it. Therefore, we would like to thank the authors for contributing their papers. The articles they have produced are sure to stimulate debate and discussion and perhaps even inspire other authors to take the leap and share their research on more or less similar topics. Thanks are also due to the numerous reviewers, whose work though unseen, has been considerable.

This issue comprises a varied selection of linguistic articles which will not only answer but might open up further research questions. The editors hope that this issue has reached one of its objectives - to cast a tiny light on two most inspiring and meanwhile most complex fields - regional linguistics and the relationship between linguistics and brand-new digitized tools to be used for research. Being aware of all this, we wish our readers a pleasant reading time and enjoying the latest issue of the Journal of Siberian Federal University. Humanities \& Social Sciences.

\title{
References
}

Brumfit, C. (2004). Applied Linguistics in 2004: Unity in Diversity? In AILA Review, 17, 133-136.

Krug, M., Schlüter, J., Rosenbach, A. (2013). Introduction: Investigating language variation and change. In Research Methods in Language Variation and Change. Ed. by Krug, M., Schlüter, J. Cambridge University Press, 1-13.

\section{Вопросы региональной лингвистики \\ и инструменты современных исследований языка: вступительная статья к лингвистическому выпуску «Журнала Сибирского федерального университета. Гуманитарные науки»}

\author{
E.C. Мучкина, О.В. Магировская \\ Сибирский федеральный университет \\ Российская Федерачия, Красноярск
}

Аннотация. Лингвистические исследования XXI века приобретают кардинально
иной характер. Это обусловлено как новыми вызовами, которые ставит перед собой
наука, так и стремлением к более широкому охвату языковой карты мира. Последнее
проявлется в огромном интересе к языкам коренных народов, требующем
детального анализа, что, в свою очередь, приведет к более глубокому пониманию
региональных культур и образа мыслей и ценностей их представителей. Не менее
важны новые лингвистические описания восточных и европейских дискурсивных
практик, которые в настоящее время активно развиваются и раскрывают менталитет 
народов, значительно влияют на модели вербального и невербального поведения и осмысления мира. Современная лингвистика также решает вопросы, которые ранее выступали приоритетными для других научных направлений. Как следствие, серьезную теоретическую основу получают жестовые языки и различные формы речевых расстройств. Такое перспективное развитие возможно благодаря богатой методологической базе исследований языка, разнообразию подходов и инструментария, доказательности существующих и разрабатываемых теорий и концепций.

Ключевые слова: региональная лингвистика, лингвокультурное наследие, цифровые инструменты анализа.

Научная специальность: 10.00 .00 - филологические науки. 